\title{
Survival of Fusarium oxysporum f. sp. vasinfectum Chlamydospores Under Solarization Temperatures
}

R. S. Bennett, Western Integrated Cropping Systems Research Unit, United States Department of Agriculture-Agricultural Research Service (USDA-ARS), Shafter, CA 93263

\begin{abstract}
Bennett, R. S. 2012. Survival of Fusarium oxysporum f. sp. vasinfectum chlamydospores under solarization temperatures. Plant Dis. 96:1564-1568.

Solarization is an effective soil treatment against race 4 of Fusarium oxysporum f. sp. vasinfectum. Despite the lack of effective alternatives, solarization is rarely used in cotton because of its high cost. Use of solarization might be increased if soil temperatures could be used to predict reductions in pathogen inoculum levels, thereby ensuring high levels of efficacy. However, relationships between survival of race 4 chlamydospores, soil moisture, and temperatures typical of solarized soil are not known. Survival of culture- and plant-produced chlamydospores of race 4 , incubated at $40^{\circ} \mathrm{C}$ in dry or moist environments, indicated the importance of moisture in determining spore survival.

Mortality of spores from either source was low under dry conditions and much higher under moist conditions. A 6-week exposure of culture-produced chlamydospores to temperatures from 30 to $40^{\circ} \mathrm{C}$ under moist conditions indicated limited mortality at temperatures $\leq 35^{\circ} \mathrm{C}$. However, most spores were eliminated by day 6 at $40^{\circ} \mathrm{C}$. A second study using a moist environment indicated high mortality of spores by 5 weeks at $37^{\circ} \mathrm{C}$ or by 10 days at temperatures from 39 to $41^{\circ} \mathrm{C}$. These results should serve as useful guides in efforts to develop solarization protocols that maximize effectiveness based on monitored soil temperatures.
\end{abstract}

Few options are currently available in California cotton (Gossypium spp.) for managing Fusarium wilt caused by race 4 of Fusarium oxysporum f. sp. vasinfectum W.C. Snyder \& H.N. Hansen (7). Availability of commercial Pima (Gossypium barbadense L.) cultivars highly resistant to race 4 are presently limited to Phytogen 800 and 805RF (Dow AgroSciences) (12,31). These cultivars accounted for $72 \%$ of the 2011 Pima acreage in California (32) but neither is immune to race 4. Significant early-season stand losses have been observed for Phytogen 800 and 805RF in sites with high levels of inoculum (R. S. Bennett, unpublished data). Furthermore, high levels of resistance to race 4 are presently unavailable in upland cotton cultivars ( $G$. hirsutum L.; 12,30), which represent $98 \%$ of U.S. cotton acreage (33). Strategies for managing populations of the root-knot nematode Meloidogyne incognita (Kofoid \& White) Chitwood $(13,18,26)$, which aid in managing Fusarium wilt caused by races 1 and 2, are not applicable to race 4 because race 4 causes severe disease in both clay loam and sandy soils in the absence of nematodes $(3,17)$.

Soil treatments for reducing pathogen inoculum are generally too costly for large-scale use in cotton but may be feasible for treating limited disease hotspots. The most effective fumigants for reducing Fusarium wilt in a recent study, 50:50 (wt/wt) methylbromide + chloropicrin, and 60:40 ( vol/vol) chloropicrin $+1,3-$ dichloropropene, cost more than $\$ 2,100 /$ acre to apply (3). How-

Corresponding author: R. S. Bennett

E-mail: rebecca.bennett@ars.usda.gov

Current address: Wheat, Peanut and Other Field Crops Research Unit, USDA-ARS, Stillwater, OK 74075.

Mention of trade names or commercial products in this article is solely for the purpose of providing specific information and does not imply recommendation or endorsement by the USDA. The USDA is an equal opportunity provider and employer.

Accepted for publication 6 May 2012.

http://dx.doi.org/10.1094/PDIS-09-11-0812-RE

This article is in the public domain and not copyrightable. It may be freely reprinted with customary crediting of the source. The American Phytopathological Society, 2012. ever, the same study found that 6 weeks of soil solarization (soil heating under transparent plastic film; 16) in July and August was as effective as fumigation for reducing soil counts of $F$. oxysporum and plant mortality. Advantages of soil solarization over fumigation include the lack of environmental and safety regulations required for application of solarization and reduced chance of creating a biological vacuum that enhances subsequent recolonization by pathogens (14). The reduction in disease from a single solarization application may also persist for multiple years (15). Unfortunately, solarization is also expensive (approximately $\$ 1,200 /$ acre for polyethylene film) and the treated area must be idled for the duration of treatment. Furthermore, treatment of disease hotspots may pose logistical challenges associated with moving plasticlaying equipment and water to remote sites within fields under production. Once in place, the treated area may obstruct the movement of irrigation water to the surrounding crop. Despite these limitations, solarization may be a viable management tactic if a high level of efficacy could be guaranteed. The efficacy of solarization might be optimized by monitoring soil temperatures and adjusting duration of treatment to maximize inoculum reduction.

Use of soil temperatures to predict inoculum reduction requires detailed knowledge of the ability of $F$. oxysporum $\mathrm{f}$. sp. vasinfectum chlamydospores to survive under solarization conditions. In the Central Valley of California, temperatures of approximately 34 to $38^{\circ} \mathrm{C}$ at a depth of $30 \mathrm{~cm}$ can be attained during the period from June through August in solarized plots (5; R. Bennett, unpublished data). Several studies have measured the effects of temperatures above $30^{\circ} \mathrm{C}$ on the viability of soilborne fungal pathogens $(8,23,27,34)$. However, few studies have examined these effects on chlamydospores of Fusarium spp., which are more resistant to heat $(2,8)$ and fumigants (10) than are conidia. Freeman and Katan (8) found that germination of $F$. oxysporum f. sp. niveum W.C. Snyder $\&$ H.N. Hansen conidia was delayed when spores were heated to 38 or $40^{\circ} \mathrm{C}$ for 30 to $90 \mathrm{~min}$. Temperatures of $40^{\circ} \mathrm{C}$ for $120 \mathrm{~min}$ or $42^{\circ} \mathrm{C}$ for $60 \mathrm{~min}$ were required to obtain similar effects on chlamydospore germination (8).

Although protocols for generating chlamydospores in media are available $(1,9,19,22)$, a deterrent to studies of factors influencing chlamydospore survival may be the relative difficulty with which high numbers of chlamydospores can be produced, relative to the production of conidia. In addition, culture-produced chlamydospores may differ from chlamydospores produced naturally in plant 
tissues. Physiological differences between culture-produced and natural inoculum have been observed for other fungi and oomycetes $(21,25)$. The objectives of this study were to compare survival of chlamydospores of $F$. oxysporum $\mathrm{f}$. sp. vasinfectum produced in culture to those produced in cotton, and to determine survival of culture-produced chlamydospores under a range of temperatures achieved during soil solarization.

\section{Materials and Methods}

Production of culture- and plant-produced chlamydospores. A race 4 isolate of $F$. oxysporum f. sp. vasinfectum, CA14 (17), was used to generate chlamydospores in culture and within cotton stems. Culture-produced chlamydospores were grown using a modification of the soil broth of Goyal et al. (9). A total of $125 \mathrm{~g}$ of air-dried SuperSoil Potting Soil (Scotts Miracle-Grow) in $500 \mathrm{ml}$ of reverse-osmosis water (Titan 500, RO Ultratech; total dissolved solids $<50 \mathrm{ppm}$ ) was agitated at $90 \mathrm{rpm}$ for $1 \mathrm{~h}$ on an orbital shaker. Ingredients listed on the label for SuperSoil Potting Soil (NPK ratio of 0.14-0.09-0.02) are peat, sphagnum peat, forest products compost or compost, urea, ureaform, monoammonium phosphate, potassium nitrate, ferrous sulfate, and a wetting agent. Large particles were removed by pouring the mixture through a 1.7-mm mesh soil sieve. The collected soil broth was filtered through eight layers of cheesecloth to remove floating particles. The twice-filtered broth was divided into three aliquots of approximately $50 \mathrm{ml}$ each. Each aliquot was autoclaved at $121^{\circ} \mathrm{C}$ for $60 \mathrm{~min}$ on two consecutive days. Sediment remaining in the sterilized broth was allowed to settle approximately $3 \mathrm{~h}$ before the liquid fraction was decanted into three sterile 125 -ml flasks. The clear soil broth was inoculated with a conidial suspension made from a 5- to 10-dayold culture on carnation leaf agar in $60-\mathrm{mm}$ petri plates. Flasks of inoculated soil broth were agitated for 7 days at room temperature ( 24 to $27^{\circ} \mathrm{C}$ ) on a bench-top orbital shaker at $90 \mathrm{rpm}$.

Mycelium-chlamydospore aggregates from flasks were removed with a sterile wooden applicator and placed in $50 \mathrm{ml}$ of sterile water in a sterile stainless steel mini-blender container (Waring Laboratory). Aggregates were broken into small clusters (one to three chlamydospores each) with five 30 -sec blending sessions. Blender containers were chilled on ice after every two blending sessions to prevent heating the spore suspension. The concentration of chlamydospores was determined using an improved Neubauer hemacytometer (Hausser Scientific). Clusters of chlamydospores not separated by hyphae were occasionally observed on the hemacytometer. These clusters were assumed to remain intact once plated on media and, thus, were counted as a single CFU.

Cotton stems infected with CA-14 were obtained from greenhouse-grown plants of the highly susceptible Pima 'DP744' (Delta and Pine Land Company; 11,17). When DP744 was planted at a high inoculum level, $F$. oxysporum f. sp. vasinfectum race 4 was isolated at nearly 3,000 CFU/g of fresh stem tissue (11). Because DP744 exhibited severe symptoms, including vascular necrosis (11), it is likely that many of the CFUs originated from chlamydospores $(24,30)$. A chlamydospore suspension, diluted to a total volume of 1 liter, was used to infest $550 \mathrm{~g}$ of a commercial potting mix (Sunshine Mix Number 1; Sun Gro Horticulture) to 3,000 chlamydospores/g. The 1-liter spore suspension was mixed into the potting mix for 30 min using a Kitchen Aid Pro Stand Mixer and the flat beater attachment. The infested potting mix was placed in a 5-liter pot and planted with 25 to 30 seeds of DP744. In total, eight pots of infested potting mix were used in the experiments, and seedlings were grown in a greenhouse set at 15.6 to $32^{\circ} \mathrm{C}$. At 17 to 21 days after planting, dead and dying seedlings were uprooted and rinsed free of soil. Seedlings, air dried for a minimum of 2 weeks at room temperature, were trimmed to collect $2.5-\mathrm{cm}-$ long stem sections from both above and below the soil line. A sample of stems was surface sterilized by immersion for $1 \mathrm{~min}$ in $95 \%$ ethanol, followed by $1 \mathrm{~min}$ in a $10 \%$ solution of household bleach $(0.6 \% \mathrm{NaOCl}, \mathrm{wt} / \mathrm{vol})$, and finally, two 1-min rinses in sterile water. Surface-sterilized stems were placed on Komada's medium (20) to confirm infection by $F$. oxysporum $\mathrm{f}$. sp. vasinfectum.
Survival of culture- and plant-produced chlamydospores. Survival of chlamydospores was assessed at $40^{\circ} \mathrm{C}$ in both dry and moist environments. For each assayed sample of culture-produced chlamydospores, $10 \mathrm{~g}$ of sterile Wasco sandy loam (coarse-loamy, mixed, superactive, nonacid, thermic Typic Torriorthents) was placed in a petri dish. Chlamydospore suspensions were diluted to $3 \times 10^{5}$ chlamydospores $/ \mathrm{ml}$ with sterile reverse-osmosis water. The spore suspension $(167 \mu \mathrm{l})$ was added to the sterile soil in 6 to12 droplets to obtain approximately 5,000 chlamydospores/g of soil. Dishes assigned to the moist treatment received an additional 1.2 $\mathrm{ml}$ of sterile water, which was a sufficient volume to disperse throughout the $10 \mathrm{~g}$ of soil within an hour. The weight of each petri dish assigned to the moist treatment was recorded on its respective lid. Petri dishes assigned to the dry treatment received no additional water.

Surface-sterilized stems were assayed in individual petri dishes lined with a sterile 5.5 -cm-diameter disk of filter paper. For dishes assigned to the moist treatment, a quadrant cut from a $5.5-\mathrm{cm}-$ diameter cotton pad was moistened with $1.5 \mathrm{ml}$ of sterile water and placed adjacent to each stem. The total weight of the dish containing the stem and moistened pad was then recorded on the dish lid.

Lids of all dishes in the chlamydospore and stem assays were secured with strips of Parafilm before the dishes were placed in a plastic container with a loose-fitting lid. The container was held in an incubator maintained at $40 \pm 0.5^{\circ} \mathrm{C}$. Temperature over the duration of exposure was monitored using a HOBO data logger (Onset). Once weekly, dishes assigned to the moist treatment were weighed and sterile water was added to compensate for evaporation.

Survival of culture-produced chlamydospores was assayed at a total of 16 exposure times $(0,1$, and 2 days and every 2 days thereafter to 28 days). Survival of chlamydospores in infected stems was assayed on the same days as for culture-produced spores, except the assays corresponding to 1 day of exposure were omitted. The experiment was conducted three times. Each repetition of experiment included four replicate dishes of each moisture and time combination for a total of 128 dishes for culture-produced chlamydospores and 120 dishes for naturally infected stems.

Survival of culture-produced chlamydospores was assessed by suspending the contents of each plate in $0.1 \%$ sterile water agar and mixing thoroughly on a stir plate. Dilutions necessary to provide $<100 \mathrm{CFU}$ per assayed plate were determined in preliminary experiments. Dilution factors ranged from 500 for plates assessed at day 0 to 2.5 for plates containing moist soil that were incubated for $>4$ days. Aliquots of soil suspension from each plate were spread on six plates (subsamples) of acidified half-strength potato dextrose agar (APDA; BD Difco), adjusted to $\mathrm{pH} 3.9$ with $10 \%$ lactic acid. Plates containing APDA were incubated at room temperature with a 12-h photophase provided by fluorescent lights, and $F$. oxysporum f. sp. vasinfectum colonies were counted after 5 to 7 days.

Survival of chlamydospores in individual stems was assessed on plates of Komada's medium incubated under the same conditions as the assay plates of culture-produced chlamydospores. Stems were rated as having viable (rating 1) or not viable (rating 0) $F$. oxysporum f. sp. vasinfectum after 5 to 14 days.

Survival of culture-produced chlamydospores under solarization temperatures. Survival of culture-produced chlamydospores in moist soil was initially tested at 30,35 , and $40^{\circ} \mathrm{C}$. A separate experiment was then conducted at 37,39 , and $41^{\circ} \mathrm{C}$ to further explore the influences of high temperatures on chlamydospore survival. Plates for both experiments were prepared and incubated as previously described. In both experiments, survival was assessed after 12 different exposure times, beginning with days 0 and 2 and at every 4 days thereafter for up to 6 weeks. Four replicate plates were prepared for each combination of temperature and incubation time for a total of 144 plates per experiment. Each experiment was conducted three times. Dilution factors necessary to obtain desired plate counts $(<100 \mathrm{CFU} /$ plate $)$ were determined in preliminary experiments. Dilution factors ranged from a maximum 
of 2,000 for assays of plates held at $30^{\circ} \mathrm{C}$ for 6 to 42 days to a minimum of 2.5 for plates held at 40 or $41^{\circ} \mathrm{C}$ for 6 to 42 days.

Statistical analyses. Survival of plant-produced chlamydospores in moist or dry environments incubated at $40^{\circ} \mathrm{C}$ was examined by logistic regression. The response variable was presence of viable $F$. oxysporum f. sp. vasinfectum in stem sections. Initial analyses using the SAS procedure PROC LOGISTIC (SAS v. 9.22) included fixed effects of moisture level, day of exposure, experimental trial, and all possible interactions. The saturated model was then simplified, retaining model hierarchy, and appropriateness of the final model was assessed by the Hosmer and Lemeshow goodness-of-fit test (LACKFIT option of the MODEL statement). The reduced model contained only main effects. Approximate means and standard errors in the original metric (probabilities) were obtained using the ILINK option of the LSMEANS statement.

Mixed-model analyses of the survival of culture-produced chlamydospores were conducted using PROC GLIMMIX of SAS, with the number of CFUs per gram of soil as the response variable. Time of exposure (days) was included as a fixed effect and repetition of experiment was considered a random effect. The combined data from dry and moist soil plates exhibited extreme heterogeneity of variance because of the marked differences in the numbers of colonies between the two moisture treatments. Therefore, data corresponding to dry and moist soil were analyzed separately. Separate analyses of chlamydospore survival under dry and moist conditions still indicated some heterogeneity of variances and nonnormality of errors. The extent of these distributional problems was minimized by analyzing the $\log _{10}$-transformed mean CFUs from the six subsamples (APDA plates) per experimental unit. In addition, incubation times at which no CFUs were observed were excluded from analyses of the moist soil plates.

Analyses of the survival of culture-produced chlamydospores at 30,35 , and $40^{\circ} \mathrm{C}$ exhibited problems with heterogeneity of variance and lack of normality similar to those encountered in the analyses of culture-produced chlamydospores in dry and moist soil. These problems were minimized by analyzing the data for each temperature separately using the same approach $\left(\log _{10}\right.$-transformed means of subsamples) as was used in analyses of culture-produced chlamydospores in moist soil. Where trends in chlamydospore survival warranted comparisons among times of exposure, experiment-wise type I error was controlled at $\alpha=0.05$ using the ADJUST=SIMULATE option of the LSMEANS statement. The identical analytical approach was used in analyses of the second experiment at 37,39 , and $41^{\circ} \mathrm{C}$. For both of the experiments examining the influence of solarization temperatures, results are presented as $\log _{10}$-transformed means and standard errors.

\section{Results}

Survival of plant- and culture-produced chlamydospores. Logistic regression indicated that presence or absence of moisture $\left(\chi^{2}=68.8 ; \mathrm{df}=1 ; P<0.01\right)$, duration of incubation $\left(\chi^{2}=38.8 ; \mathrm{df}\right.$ $=14 ; P<0.01)$, and trial $\left(\chi^{2}=12.6 ; \mathrm{df}=2 ; P<0.01\right)$ influenced the probability of recovering $F$. oxysporum $\mathrm{f}$. sp. vasinfectum from infected stems incubated at $40^{\circ} \mathrm{C}$. Viable chlamydospores were isolated from all stems incubated in a dry environment regardless of exposure time (mean probability $=1.0$ ). The probability of recovering $F$. oxysporum f. sp. vasinfectum from stems incubated in a moist environment was significantly influenced by duration of incubation $\left(\chi^{2}=39.7\right.$; df $=14 ; P<0.01$; Fig. 1$)$. The mean probability of survival declined rapidly from day $0(0.91 \pm 0.08)$ to day $10(0.05 \pm 0.06)$.

Although the influence of moisture level was not tested in analyses of survival of culture-produced chlamydospores, trends similar to those observed for survival of plant-produced spores were apparent (Fig. 1). Culture-produced chlamydospores incubated on dry soil at $40^{\circ} \mathrm{C}$ were still viable after 28 days of incubation but survival of chlamydospores incubated on moist soil declined rapidly (Fig. 1). No colonies were recovered from chlamydospores incubated on moist soil for more than 14 days at $40^{\circ} \mathrm{C}$ (data for longer durations were excluded from analysis). Survival of chlamydospores declined through the first 4 to 6 days of incubation regardless of moisture level (dry: $F=28.54$; df $=15,172 ; P<$ 0.01 ; moist: $F=307.97$; df $=8,96.01 ; P<0.01)$.

The number of CFUs recovered at day 0 from both the dry and moist soil plates was more than twice the calculated quantity applied to the soil. This apparent error was probably caused by the presence of viable mycelial fragments and conidia in the chlamydospore suspension, both of which were visible on the hemacytometer when chlamydospores were quantified. The number of viable chlamydospores in the dry soil plates declined nearly 10fold between day 0 and day $1(P=0.01)$. This decline may have resulted from lethal desiccation of mycelium and conidia. However, the number of CFUs per plate stabilized by day 4. Comparisons of chlamydospore survival at incubation times between days 4 and 28, inclusive, indicated that only colony counts on day 16 of incubation were significantly lower than those on day 4 (Fig. 1).

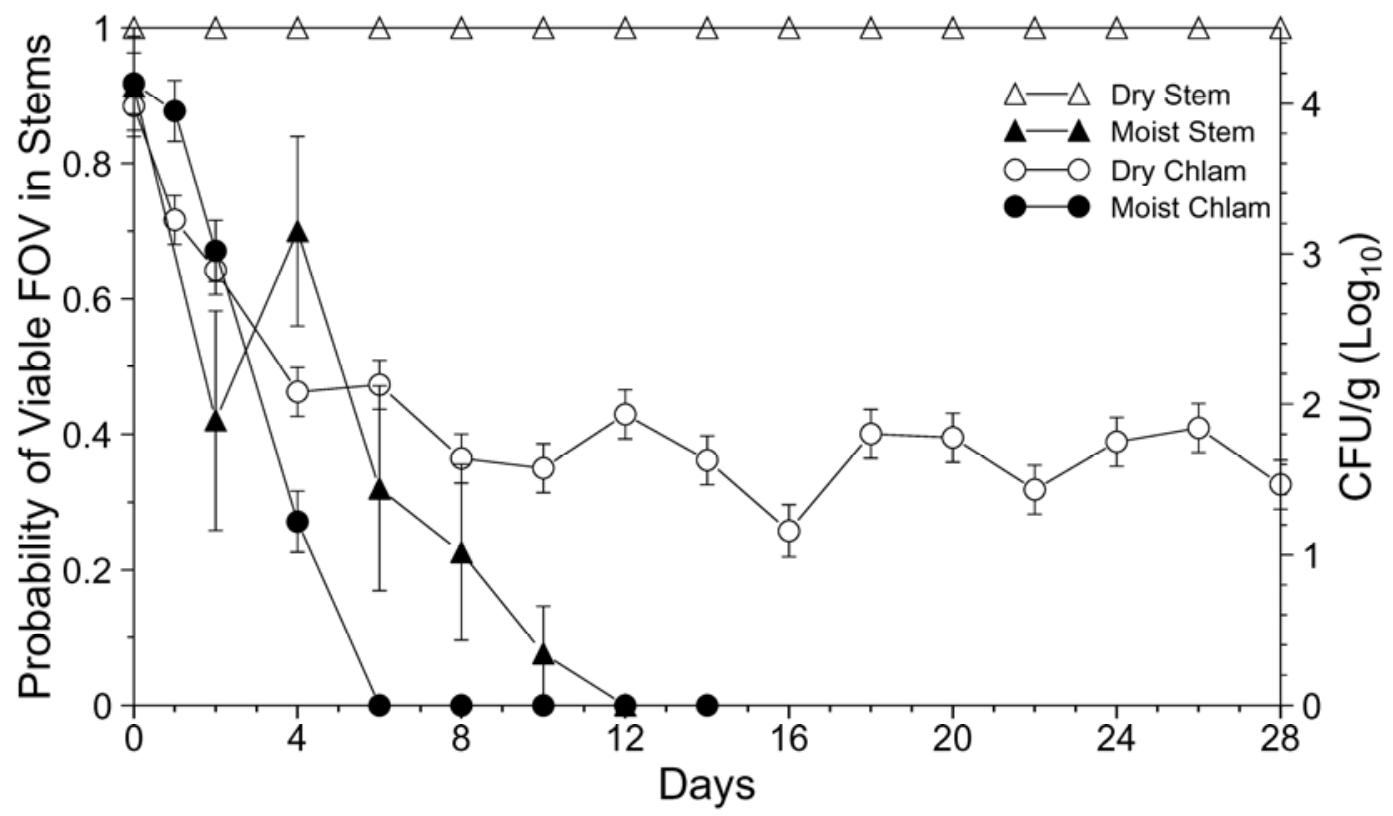

Fig. 1. Survival of plant- and culture-produced Fusarium oxysporum f. sp. vasinfectum (FOV) chlamydospores (probability \pm standard error [SE]; mean log ${ }_{10} \mathrm{CFU} \pm \mathrm{SE}$, respectively) exposed to $40^{\circ} \mathrm{C}$ under dry or moist conditions. 
The comparatively low colony count corresponding to day 16 of incubation did not reflect a meaningful trend in the data and may represent sampling error. In contrast to survival on dry soil, survival of chlamydospores incubated on moist soil declined rapidly from nearly $14,000 \mathrm{CFU} / \mathrm{g}$ at day 0 to $23 \mathrm{CFU} / \mathrm{g}$ at day 4 . Fewer than $1 \mathrm{CFU} / \mathrm{g}$ was recovered from moist chlamydospore plates incubated at $40^{\circ} \mathrm{C}$ between 8 to 14 days.

Survival of culture-produced chlamydospores under solarization temperatures. In the experiment testing survival of culture-produced chlamydospores incubated at 30,35 , and $40^{\circ} \mathrm{C}$, the duration of incubation influenced survival at all temperatures $\left(30^{\circ} \mathrm{C}: F=60.88 ; \mathrm{df}=11,130 ; P<0.01 ; 35^{\circ} \mathrm{C}: F=6.87 ; \mathrm{df}=11\right.$, 130; $P<0.01 ; 40^{\circ} \mathrm{C}: F=750.75$; df $=2,31 ; P<0.01$; Fig. 2$)$. At $30^{\circ} \mathrm{C}$, conditions were favorable for growth of $F$. oxysporum f. sp. vasinfectum and mycelium was visible on the surface of many plates. Significantly fewer colonies were recovered from plates incubated at $30^{\circ} \mathrm{C}$ at day 0 than at other days $(P<0.01)$. Plates incubated 6 to 42 days at $30^{\circ} \mathrm{C}$ did not differ in the number of colonies recovered $(P>0.46)$. At $35^{\circ} \mathrm{C}$, chlamydospore survival declined over time, and the number of colonies recovered at day 0 was significantly higher than at days $>26(P<0.01)$. However, nearly $1,000 \mathrm{CFU} / \mathrm{g}$ were still recovered after 42 days of incubation (Fig. 2). No colonies were recovered from plates incubated $\geq 10$ days at $40^{\circ} \mathrm{C}$. At $40^{\circ} \mathrm{C}$, the number of colonies decreased sharply from over $16,000 \mathrm{CFU} / \mathrm{g}$ at day 0 to less than $1 \mathrm{CFU} / \mathrm{g}$ by day 6 (Fig. 2).

In the second experiment, evaluating survival at 37,39 , and $41^{\circ} \mathrm{C}$, no colonies were recovered after 18 days of incubation at $39^{\circ} \mathrm{C}$ or after 6 days at $41^{\circ} \mathrm{C}$ (Fig. 2). Duration of incubation influenced chlamydospore survival at all temperatures $\left(37^{\circ} \mathrm{C}: F=\right.$ 76.21; df $=11,90.13 ; P<0.01 ; 39^{\circ} \mathrm{C}: F=194.19 ; \mathrm{df}=5,39 ; P<$ $\left.0.01 ; 41^{\circ} \mathrm{C}: F=254.39 ; \mathrm{df}=2,21 ; P<0.01\right)$. Nearly all chlamydospores incubated at $37^{\circ} \mathrm{C}$ were dead after 34 days. At $39^{\circ} \mathrm{C}$, the number of colonies recovered was nearly 0 and not significantly different among incubation times from 10 to 18 days $\left(P>0.53\right.$; Fig. 2). Viability of chlamydospores incubated at $41^{\circ} \mathrm{C}$ was similar to that at $40^{\circ} \mathrm{C}$, with numbers of colonies declining sharply until fewer than $1 \mathrm{CFU} / \mathrm{g}$ were recovered by day 6 (Fig. 2).

\section{Discussion}

Observed survival trends of plant- and culture-produced chlamydospores held at $40^{\circ} \mathrm{C}$ in the presence or absence of moisture were similar. In soil solarization, moisture is usually applied because the presence of water increases thermal sensitivity of pathogens $(14,16,23,28,34)$. In this study, chlamydospores of $F$. oxysporum f. sp. vasinfectum also appeared more sensitive to high temperatures in the presence of water than under dry conditions. Under dry conditions, many plant- and culture-produced chlamydospores remained viable after 28 days of incubation at $40^{\circ} \mathrm{C}$. Under moist conditions at $40^{\circ} \mathrm{C}$, survival of chlamydospores from both sources declined rapidly, and nearly all were dead after 10 days of incubation. Although data from infected stems were qualitative, colony emergence from moist stems incubated for several days at $40^{\circ} \mathrm{C}$ was noticeably delayed compared with emergence from stems assayed at day 0 (data not shown). This delayed emergence may have resulted from deleterious effects of heat treatment on chlamydospore survival, germination, and growth. Freeman and Katan (8) observed significantly slower germ tube growth in surviving chlamydospores of $F$. oxysporum $\mathrm{f}$. sp. niveum after 2 $\mathrm{h}$ of exposure to moist heat at $40^{\circ} \mathrm{C}$.

Because survival of culture- and plant-produced chlamydospores was reasonably similar, only culture-produced chlamydospores were used to test survival under a range of temperatures typical of solarized soil. Culture-produced chlamydospores could be produced more quickly than plant-produced chlamydospores, which allowed collection of more quantitative data. Most chlamydospores were killed within 10 days of exposure to moist heat at temperatures from 39 to $41^{\circ} \mathrm{C}$. In contrast, nearly 5 weeks of incubation were required to kill most chlamydospores at $37^{\circ} \mathrm{C}$. Chlamydospore survival declined slightly with incubation under moist conditions at $35^{\circ} \mathrm{C}$ but colony counts remained high even after 42 days of exposure. Although soil temperatures obtained under solarization vary with soil depth, temperatures of 39 to $40^{\circ} \mathrm{C}$ are achievable at depths $\leq 20 \mathrm{~cm}$ during summer in the Central Valley $(5,27 ; \mathrm{R}$. $\mathrm{S}$. Bennett, unpublished data). At a depth of $30 \mathrm{~cm}$, soil temperatures may fluctuate from 34 to $38^{\circ} \mathrm{C}$ (5). In practice, the temperatures achieved by solarization will vary among sites and time and with local weather conditions (4). For example, the maximum soil temperatures achieved between May and September in Davis, CA at a depth of $15 \mathrm{~cm}$ varied between 39 and $48^{\circ} \mathrm{C}(27,29)$. Therefore, even if the relationship between temperature and pathogen mortality is known, it may be necessary to monitor solarization temperatures to ensure consistent results.

Durations necessary for effective solarization were estimated for Verticillium dahliae, Pythium ultimum, Rhizoctonia solani, and Thielaviopsis basicola based on models of thermal death rates (27). Pullman and colleagues used constant temperatures and axenic cultures of these pathogens, as was used in this report, to determine

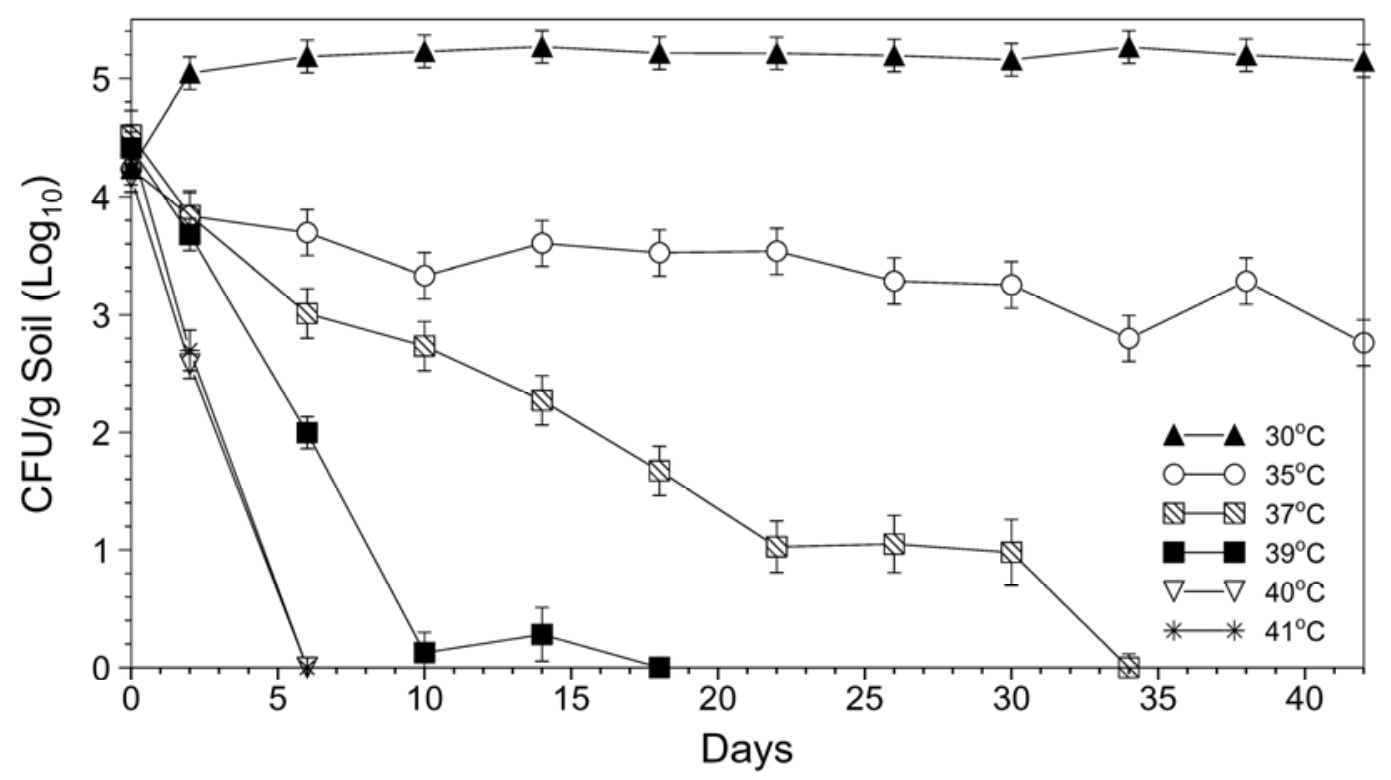

Fig. 2. Mean $\log _{10} \mathrm{CFU} / \mathrm{g}$ ( \pm standard error) recovered from culture-produced Fusarium oxysporum f. sp. vasinfectum chlamydospores incubated in moist soil at 30,35 , and $40^{\circ} \mathrm{C}$ (experiment 1 ) and at 37,39 , and $41^{\circ} \mathrm{C}$ (experiment 2). 
$90 \%$ lethal dose exposure times at 37 to $50^{\circ} \mathrm{C}$ (27). Much work remains to determine whether thermal death rates under simulated solarization temperatures are useful predictors of survival of inoculum under field conditions. Constant temperatures were used in these experiments but soil temperatures fluctuate diurnally. Shlevin et al. (28) studied the effect of fluctuating greenhouse temperatures (less than or equal to approximately $60^{\circ} \mathrm{C}$ ) on chlamydospore survival but the influence of fluctuating temperatures typically achieved during soil solarization is not known. Short durations of high temperatures may be sufficient to kill or weaken chlamydospores (8) but fluctuating temperatures may possibly induce heat resistance (6). Chlamydospores of $F$. oxysporum f. sp. dianthi pretreated at $45^{\circ} \mathrm{C}$ demonstrated significantly less mortality after exposure to $55^{\circ} \mathrm{C}$ than chlamydospores receiving no pretreatment (6). In addition to potential differences between constant and fluctuating temperatures, the absence of antagonistic or competing microorganisms in this study may have influenced relevance of these results to field conditions. Mortality of heat-treated $V$. dahliae (27) and $F$. oxysporum f. sp. niveum (8) was more rapid in nonsterile soil than in axenic culture. Finally, the focus of the current study was pathogen mortality but heat treatment has also been shown to reduce virulence in $F$. oxysporum conidia (8). Therefore, chlamydospores surviving heat treatment may also be reduced in virulence. In that case, solarization may be more effective than is indicated by estimates of pathogen mortality. Careful examination of these aforementioned factors will be necessary in order to develop a realistic model of thermal death rates for $F$. oxysporum $\mathrm{f}$. sp. vasinfectum under field conditions.

\section{Acknowledgments}

G. Martinez, J. Salinas, J. Liebenow, and B. Atwood provided laboratory assistance.

\section{Literature Cited}

1. Alexander, J. V., Bourret, J. A., Gold, A. H., and Snyder, W. C. 1966. Induction of chlamydospore formation by Fusarium solani in sterile soil extracts. Phytopathology 56:353-354.

2. Barran, L. R. 1980. Effect of heat, freeze-thawing and desiccation on the survival of Fusarium sulphureum spores. Trans. Br. Mycol. Soc. 75:425427.

3. Bennett, R. S., Spurgeon, D. W., DeTar, W. R., Gerik, J. S., Hutmacher, R. B., and Hanson, B. D. 2011. Efficacy of four soil treatments against Fusarium oxysporum f. sp. vasinfectum race 4 on cotton. Plant Dis. 95:967976.

4. Ben-Yephet, Y., Melero-Vera, J. M., and DeVay, J. E. 1988. Interaction of soil solarization and metam-sodium in the destruction of Verticillium dahliae and Fusarium oxysporum f. sp. vasinfectum. Crop Prot. 7:327-331.

5. Ben-Yephet, Y., Stapleton, J. J., Wakeman, R. J., and DeVay, J. E. 1987. Comparative effects of soil solarization with single and double layers of polyethylene film on survival of Fusarium oxysporum f. sp. vasinfectum. Phytoparasitica 15:181-185.

6. Castejón-Muñoz, M., and Bollen, G. J. 1993. Induction of heat resistance in Fusarium oxysporum and Verticillium dahliae caused by exposure to sublethal heat treatments. Eur. J. Plant Pathol. 99:77-84.

7. Davis, R. M., Colyer, P. D., Rothrock, C. S., and Kochman, J. K. 2006. Fusarium wilt of cotton: population diversity and implications for management. Plant Dis. 90:692-703.

8. Freeman, S., and Katan, J. 1988. Weakening effect on propagules of Fusarium by sublethal heating. Phytopathology 78:1656-1661.

9. Goyal, J. P., Maraite, H., and Meyer, J. A. 1973. Abundant production of chlamydospores by Fusarium oxysporum f. sp. melonis in soil extract with glucose. Neth. J. Plant Pathol. 79:162-164.

10. Goyal, J. P., Maraite, H., and Meyer, J. A. 1974. Relative susceptibility of various propagules of Fusarium oxysporum f. sp. melonis to chloropicrin under conditions controlled by a new laboratory apparatus. Agric. Environ. $1: 259-264$.
11. Hao, J. J., Yang, M. E., and Davis, R. M. 2009. Effect of soil inoculum density of Fusarium oxysporum f. sp. vasinfectum race 4 on disease development in cotton. Plant Dis. 93:1324-1328.

12. Hutmacher, R. B., Ulloa, M., Davis, R. M., Wright, S. D., Marsh, B. Goodell, P., Banuelos, G., Keely, M., and Munk, D. 2010. Assessment of Acala/Upland and Pima cottons response to Fusarium wilt disease in the San Joaquin Valley. Page 791 in: Proc. Beltwide Cotton Conf. Natl. Cotton Counc. Am. New Orleans, LA.

13. Jorgenson, E. C., Hyer, A. H., Garber, R. H., and Smith, S. N. 1978. Influence of soil fumigation on the Fusarium-root-knot nematode disease complex of cotton in California. J. Nematol. 10:228-231.

14. Katan, J. 1981. Solar heating (solarization) of soil for control of soilborne pests. Annu. Rev. Phytopathol. 19:211-236.

15. Katan, J., Fishler, G., and Grinstein, A. 1983. Short-and long-term effects of soil solarization and crop sequence on Fusarium wilt and yield of cotton in Israel. Phytopathology 73:1215-1219.

16. Katan, J., Greenberger, A., Alon, H., and Grinstein, A. 1976. Solar heating by polyethylene mulching for the control of diseases caused by soil-borne pathogens. Phytopathology 66:683-688.

17. Kim, Y., Davis, R. M., and Hutmacher, R. B. 2005. Characterization of California isolates of Fusarium oxysporum f. sp. vasinfectum. Plant Dis. 89:366-372.

18. Kirkpatrick, T. L., and Sasser, J. N. 1984. Crop rotation and races of Meloidogyne incognita in cotton root-knot management. J. Nematol. 16:323-328.

19. Klotz, L. V., Nelson, P. E., and Toussoun, T. A. 1988. A medium for enhancement of chlamydospore formation in Fusarium species. Mycologia $8: 108-109$.

20. Komada, H. 1975. Development of a selective medium for quantitative isolation of Fusarium oxysporum from natural soil. Rev. Plant Prot. Res. $8: 114-125$.

21. Linderman, R. G., and Gilbert, R. G. 1973. Behavior of sclerotia of Sclerotium rolfsii produced in soil or in culture regarding germination stimulation by volatiles, fungistasis, and sodium hypochlorite treatment. Phytopathology 63:500-504.

22. Locke, T., and Colhoun, J. 1974. Contributions to a method of testing oil palm seedlings for resistance to Fusarium oxysporum Schl. f. sp. elaeidis Toovey). J. Phytopathol. 79:77-92.

23. Matheron, M. E., and Porchas, M. 2005. Influence of soil temperature and moisture on eruptive germination and viability of sclerotia of Sclerotinia minor and S. sclerotiorum. Plant Dis. 89:50-54.

24. Nash, S. M., Christou, T., and Snyder, W. C. 1961. Existence of Fusarium solani f. phaseoli as chlamydospores in soil. Phytopathology 51:308-312.

25. Nelson, E. B., and Craft, C. M. 1989. Comparative germination of cultureproduced and plant-produced sporangia of Pythium ultimum in response to soluble seed exudates and exudate components. Phytopathology 79:1009 1013

26. Ogallo, J. L., Goodell, P. B., Eckert, J., and Roberts, P. A. 1997. Evaluation of NemX, a new cultivar of cotton with high resistance to Meloidogyne incognita. J. Nematol. 29:531-537.

27. Pullman, G. S., DeVay, J. E., and Garber, R. H. 1981. Soil solarization and thermal death: a logarithmic relationship between time and temperature for four soilborne plant pathogens. Phytopathology 71:959-964.

28. Shlevin, E., Mahrer, Y., and Katan, J. 2004. Effect of moisture on thermal inactivation of soilborne pathogens under structural solarization. Phytopathology 94:132-137.

29. Stapleton, J. J., and DeVay, J. E. 1983. Response of phytoparasitic and freeliving nematodes to soil solarization and 1,3-dichloropropene in California Phytopathology 73:1429-1436.

30. Trujillo, E. E., and Snyder, W. C. 1963. Uneven distribution of Fusarium oxysporum f. cubense in Honduras soils. Phytopathology 53:167-170.

31. Ulloa, M., Hutmacher, R. B., Davis, R. M., Wright, S. D., Percy, R., and Marsh, B. 2006. Breeding for Fusarium wilt race 4 resistance in cotton under field and greenhouse conditions. J. Cotton Sci. 10:114-127.

32. USDA Agricultural Marketing Service. 2011. Cotton varieties planted: 2011 crop. USDA-AMS, Cotton Program, publ. mp_cn833.

33. USDA National Agricultural Statistics Service. 2011. Crop Production. Retrieved 27 September 2011 from http://usda.mannlib.cornell.edu/usda/ nass/CropProd/2010s/2011/CropProd-09-12-2011.pdf

34. Wu, B. M., Subbarao, K. V., and Liu, Y. B. 2008. Comparative survival of sclerotia of Sclerotinia minor and S. sclerotiorum. Phytopathology 98:659665 . 